\title{
Changes in Education, Religion, Social, Economic, Culture, and Politics in Egypt Post-Napoleon Invasion
}

\author{
Hatib Rahmawan ${ }^{1}$ \\ ${ }^{1}$ Prodi Ilmu Hadis Fakultas Agama Islam, Universitas Ahmad Dahlan Yogyakarta
}

\begin{tabular}{|c|c|}
\hline Article Info & ABSTRACT \\
\hline Article history: & The important role of Egypt in the Resurrection of the Islamic world is did not \\
\hline Received Agustus 17, 2019 & happen suddenly, but he had to go through a dark history, that was colonialized \\
\hline Accepted September 20, 2019 & but his presence woke the Egyptian consciousness to progress and change. \\
\hline & $\begin{array}{l}\text { This paper aims to uncover the changes that occurred in Egypt in the fields of } \\
\text { education. issues, economy, culture, and politics post-Napoleon invasion. }\end{array}$ \\
\hline & $\begin{array}{l}\text { From this, a main problem can be formulated as follows; How was the change } \\
\text { in education, religion, social, economy, culture, and politics post-Napoleon }\end{array}$ \\
\hline Post Napoleon & invasion? This paper uses the liberary research method, which is combined \\
\hline Egypt & with the model of writing history to reveal the relationship between historical \\
\hline Changes & facts with changes that occured. The important information obtained from this \\
\hline Islamic Education & $\begin{array}{l}\text { post-Napoleon study include; (1) in the field of education raises awareness of } \\
\text { the underdevelopment of science, the development of various educational } \\
\text { infrastructure, recognizing the importance of freedom and independence in the } \\
\text { development of science; (2) Encouraging changes in perspectives and models } \\
\text { of religion towards a more rational and solutions to the changing times; (3) in } \\
\text { the social and cultural sphere the idea of equality (legalite) and equality } \\
\text { between rulers and people was born and the development of war technology, } \\
\text { weapons and military training adopted from France; (4) in the political field } \\
\text { gave rise to the idea of nationalism and republican government; and (5) in the } \\
\text { economic field to encourage the development of industrialization and agrarian } \\
\text { reform. }\end{array}$ \\
\hline
\end{tabular}

This is an open access article under the CC BY-SA license.

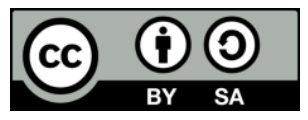

\section{Corresponding Author:}

Hatib Rahmawan

Dosen Prodi Ilmu Hadis Fakultas Agama Islam, Universitas Ahmad Dahlan Yogyakarta

E-mail: hatib.rahmawan@ilha.uad.ac.id

\section{PENDAHULUAN}

Mesir merupakan salah satu negara di benua Afrika yang secara historis sangat dekat dengan dunia Arab. Letak geografis yang menghubungan dua benua menjadikan negeri ini sangat strategis. Letak Mesir berbatasan dengan Libya di sebelah barat, Sudan di selatan, dan Jalur Gaza dan Israel di utara-timur. Perbatasannya dengan perairan ialah melalui Laut Tengah di utara dan Laut Merah di timur (Afaf Lutfi AlSayyid Marsot, 2007: xi-xii).

Selain kebesaran sejarah masa lalu, (Arnold Toynbee, tt: 95, 144, 183, 223) Mesir di mata negaranegara Islam - lebih tepatnya mayoritas Muslim, menjadi figur sentral inspirasi pembaruan Islam. Setidaknya dari negeri ini lahir tokoh-tokoh pembaharu Islam yang pengaruhnya sangat kuat hingga saat ini (Mukti Ali, 2000: 11-14). Mulai dari Jamaluddin Al-Afghani, Muhammad Abduh, Muhammad Husain Haikal, dan Rasyid Ridha (Anhar Anshori, 2019: 53).

Mesir menjadi pusat pembaruan Islam di dunia bukanlah hal yang tiba-tiba. Mesir harus lebih dulu mengalami keterpurukan di bawah kepemimpinan Turki Usmani, Mamluk, dan penjajahan bangsa Prancis di bawah Jendral Napoleon Bonaparte (Afaf Lutfi Al-Sayyid Marsot, 2007: 1, 31, 65). Sejarah kelam tersebut patut disyukuri, sebab mampu memberikan kesadaran pembaruan bagi bangsa Mesir. Tanpa hal 
tersebut mungkin Mesir masih dalam feodalisme dan otoritarianisme.

Dari sederatan sejarah kelam tersebut kehadiran Napoleon adalah yang paling banyak memantik kesadaran bangsa Turki. Sebab Napoleon tidak hanya hadir untuk melakukan penjajahan, melainkan juga membawa angin segar peradaban baru. Mungkin lebih tepatnya, Napoleon tidak hadir untuk melakukan invasi, melainkan ekspedisi. Sebab kekuasaan Napoleon hanya bertahan selama tiga tahun.

Dalam waktu yang singkat tersebut, rupanya membawa inspirasi yang luar biasa dalam panggung sejarah peradaban Islam pada umumnya, dan Mesir secara khusus. Makalah ini mencoba membahas pengaruh ekspedisi Napoleon di Mesir terhadap perubahan pendidikan, agama, sosial, budaya, ekonomi, dan politik. Dari latar belakang di atas maka dapat dirumuskan sebuah pokok permasalahan sebagai berikut: Bagaimana perubahan pendidikan, agama, sosial, budaya, dan politik di Mesir pasca Napoleon Bonaparte?

\section{METODE}

Makalah ini menggunakan metode liberary research (penelitian kepustakaan). Langkahnya adalah dengan cara mengumpulkan berbagai sumber yang berasal dari buku-buku dan tulisan-tulisan yang tersebar di berbagai jurnal. Tema makalah ini adalah masalah sejarah, oleh karena itu penulisannya yang paling tepat menggunakan metode penulisan historis. Adapun salah satu bentuk dari teknik penulisan sejarah dalam makalah ini adalah metode penulisan sejarah ilmiah. Penulisan sejarah ilmiah bertujuan mencari pertautan sebab akibat dan continuity antara satu peristiwa ke peristiwa lainnya sehingga didapat pemahaman yang utuh (Nourouzaman As-Sidiqi, 1989: 77).

\section{HASIL DAN PEMBAHASAN}

\subsection{Kondisi Mesir Sebelum Napoleon}

\section{Kemerosotan Kepemimpinan}

Sebelum membahas ekspedisi Napoleon di Mesir, ada baiknya kita kembali melihat Mesir sebelum terjadi penaklukan. Dengan mengetahui kondisi pra ekspedisi maka seorang analis atau pembaca dapat mengamati sejauh mana fakta-fakta sejarah memberikan pengaruh pada perubahan di Mesir. Salah satu imperium yang pernah menguasai Mesir adalah Dinasti Fatimiyah. Dinasti ini berkuasa selama 280 tahun(Hamka, 1975:185).

Sebenarnya dinasti ini merupakan bentukan dari generasi Ubaidiyun di Afrika. Jauhar, salah seorang panglima perang yang gagah berani dan cerdas akhirnya mampu menguasai Mesir. Dikarenakan ia menganut paham Syi'ah nama dinasti Ubaidiyah diganti dengan Fatimiyah, yang dinisbatkan kepada anak perempuan Nabi Muhammad saw. Pada masa kekuasaan dinasti ini, Mesir mengalami kejayaan dan kemakmuran, hampir menyaingi Cordoba dan Baghdad (Hamka, 1975:185).

Sebagai bentuk peringatan atas kegemilangan dinasti tersebut dibentuklah kota yang diberi nama 'Qahirah' (sekarang menjadi Kairo), artinya 'kegemilangan'. Dibangun juga Masjid al-Azhar yang diambilkan dari julukan anak perempuan Nabi saw. (Fatimah), yakni 'az-Zahra'. Jamak dari kata 'AzZahra' adalah 'Al-Azhar'. Masjid ini digunakan untuk mengajarkan paham syi'ah sebagai paham resmi Negara (Hamka, 1975:185). Dalam perkembangannya masjid ini menjadi komplek pendidikan tertua, yaitu Universitas al-Azhar (Stvelana Kirillina, 2004: 36-39)

Dinasti Fatimiyah mulai mengalami kemerosotan ketika dipegang oleh Abu Ali Mansur al-Hakim (996-1021), anak al-Aziz, yang diangkat sebagai raja pada umur 11 tahun. Kepemimpinannya ditandai dengan tindakan-tindakan kejam dan menakutkan. Ia membunuh beberapa orang wazirnya, menghancurkan beberapa gereja Kristen. Ia memaksa orang-orang Yahudi dan Nasrani untuk memakai jubah hitam, dan hanya membolehkan mereka menunggang keledai. Raja ini akhirnya terbunuh oleh saudara perempuannya sendiri yang ketika kecil pernah dilecehkan. Kekuasaan kerajaan kemudian dipegang oleh para wazirnya, dan lambat laun kekuasaan kerajaan berkurang (Philip K, 2005: 792).

Setelah Dinasti Fatimiyah, kekuasaan dipegang oleh Dinasti Mamluk. Kata mamaluk merupakan bentuk jamak dari kata 'mamluk' yang artinya budak. Memang aslinya dinasti ini didirikan oleh para budak (Badri Yatim, 2000: 124). Raja Pertamanya adalah Aybak (1250-1257 M) (Wahyudin Darmalaksana, 2009: 121). Salah satu yang termasyhur diantara pemimpin dinasti ini adalah Sultan Baybars (1260-1277) yang sanggup mengalahkan panglima Hulagu Khan dalam perang 'Ain Jalut. Dinasti Mamluk berkuasa di Mesir sampai tahun 1517 M (Badri Yatim, 2000: 125). Mereka inilah yang terkenal sanggup membebaskan Mesir dan Suriah dari peperangan Salib serta yang membendung kedahsyatan tentara Mogol di bawah pimpinan Hulagu dan Timur Lenk (Badri Yatim, 2000: 125).

Asal-usul kaum Mamluk berasal dari daerah pengunungan Kaukasus, yaitu daerah pengunungan yang berbatasan antara Rusia dan Turki. Mereka didatangkan ke Istambul untuk dididik menjadi militer. Dalam perkembangan selanjutnya kedudukan mereka dalam kemiliteran meningkat. Bahkan di antara mereka ada yang dapat mencapai jabatan militer yang tinggi (Harun Nasution, 1986: 59). Akhirnya, di antara mereka ada yang mengambil alih daerah kekuasaan Turki Usmani, membangkang dan tidak tunduk pada Istambul. 
Mesir di bawah kekuasaan Mamluk kian menurun pamornya, terutama setelah Sultan Baybar mangkat. Ada dua factor penyebabnya, internal dan eksternal. Faktor internal berupa perebutan kekuasaan antar keturunan yang mengakibatkan bunuh-membunuh. Akibat perebutan tersebut pemerintahan terbengkalai, keamanan kerajaan tidak diperhatikan (Arthur Goldschmidt, 2008:53). Kepemimpinan Mamluk berhasil direbut oleh Syekh Balad, tetapi Syekh Balad sering bertabiat kasar, sehingga hubungan mereka dengan rakyat Mesir tidak baik. Hal ini salah satu faktor yang memudahkan tentara Napoleon menguasai daerah-daerah yang dikuasai Mamluk (Drs. H.M. Yusran Asmuni, 1998: 65-66). Faktor selanjutnya dalah serangan-serangan dari luar daerah terutama oleh pasukan Portugis dan para pemberontak.

Silih bergantinya penguasa, akhirnya membuat kondisi Mesir kacau balau. Situasi kekuasaan dan pemerintahan di Mesir pada waktu itu sudah tidak dapat lagi dikatakan stabil. Kekacauan, kemerosotan sosial-kemasyarakatan, dan peperangan sungguh-sungguh membuat rakyat Mesir diliputi rasa ketakutan. Dalam keadaan sedemikian lemah, datanglah Napoleon dengan pasukan tempurnya. Hadirnya untuk melebarkan sayap imperial ke wilayah-wilayah yang mempunyai potensi kekayaan alam, peradaban, dan warisan-warisan historis. Tujuannya tidak lain untuk mencari batu pijakan membangun impian menguasai dunia.

\section{Kondisi Sosial-Budaya-Pendidikan Mesir}

Kondisi politik yang kacau akhirnya berdampak pada proses pendidikan di Mesir. Ilmu pengetahuan dan pendidikan terbengkalai. Hal yang diperhatikan hanya penguatan pasukan perang. Sistem pembelajaran dilakukan dengan cara doktrinal, khususnya dalam hal agama. Karena ilmu pengetahuan umum diabaikan. Murid dijadikan seperti robot, menghafal di luar kepala tanpa ada pengkajian kritis, evaluasi bahkan telaah pemahaman. Metode seperti ini akhirnya membuat ajaran-ajaran Islam menjadi dogma yang kaku, statis tidak berkembang. Karena tidak berkembang, akhirnya mempelajari agama tidak memberikan perubahan apa-apa dalam kehidupan.

Otak manusia dianggap seperti botol kosong yang harus diisi air. Para murid dan mahasiswa menerima apa adanya. Diskusi dan dialog menjadi barang langka dalam pengkajian keislaman. Akhirnya kebenaran tunggal terletak hanya di tangan dan kepala para guru. Otoritariansime mulai merambah duania pendidikan. Selain itu akibat pengaruh al-Gahzali yang melarang filsafat dan logika, kedua materi kuliah tersebut dibuang dari kurikulum sekolah (Mukti Ali, 2000: 39-50). Keduanya dianggap tabu (bahkan menyesatkan) untuk dipelajari. Sebagaimana dikatakan Muhammad Abduh, ia merasa jenuh dengan cara menerima ilmu dengan metode menghafal luar kepala (Harun Nasution, 1986: 59). Lebih jauh Muhamamd Abduh menggambarkan bahwa metode pendidikan yang otoriter juga merupakan salah satu pendorong mandegnya kebebasan intelektual, sehingga ia sendiri merasa tidak begitu tertarik mendalami agama pada masa kecil lantaran kesalahan metode itu, yakni berupa cara menghafal pelajaran di luar kepala(T. Al-Tanawi, tt: 29).

Pola belajar yang rusak seperti itu tentu berpengaruh pada kondisi masyarakat. Realitas sosialkeagamaan secara umum pada waktu itu didominasi model berpikir jabariyah. Itu disebabkan karena berkembangnya paham tasawuf. Tarekat-tarekat bermunculan bak cendawan di Musim hujan. Mereka banyak sekali melupakan kondisi masyarakat yang parah, sibuk mencari surga. Zuhud ekstrem dari metode tarekat membuat umat Islam lebih berusaha mengurusi alam ghaib, ketimbang dunia realitas. Pelarian kepada dunia akhirat membuat umat Islam tidak mempunyai semangat perjuangan melawan dominasi kezaliman di sekitarnya, termasuk kezaliman penguasa. Guru-guru tarikat akhirnya menjadi top figure dalam kepemimpinan agama.

Pengkultusan individu tentu terjadi di dunia tarekat ini. Setelah meninggal dunia, sang imam atau para syaikh tarekat ini masih dimuliakan dan dianggap sebagai wali yang selalu diziarahi dan disembah-sembah. Dijadikan wasilah untuk bertemu Tuhan. Namun umat Islam yang menziarahi itu tidak benar-benar menginsyaratkan kepada akhirat, tapi hanya meminta berkah dan mengais keberuntungan material terhadap makna kekeramatan yang dihajatkan mereka. Pada klimaksnya, timbullah pengkultusan individu berlebihan yang membuat seseorang akan mudah terpuruk kepada perilaku menyekutukan Allah. Karena mereka lebih mengutamakan meminta kepada para wali yang ada di dalam kubur sehingga mengabaikan berdoa langsung kepada Tuhan. Kondisi sosial-keagamaan seperti itu, sebagaimana dilukiskan oleh Muhammad al-Bahy telah membuat rakyat Mesir khususnya dan dunia Islam pada umumnya lebih mementingkan tindakan individual. Ukhuwah Islamiyah yang menekankan kepada kebersamaan, persatuan, dinamisme hidup, rasionalitas berpikir dalam lapangan keagamaan, dan sebagainya telah hilang di kalangan umat Islam. Termasuk di kalangan Universitas Al-Azhar sendiri, yang digambarkan oleh Muhammad Abduh sudah kehilangan roh intelektual dan jihad keagamaan yang berpijak kepada kebenaran Al-Qur'an dan Sunnah Nabi (Muhammad Al-Bahy, 1986: 90-92). 


\section{Ekspedisi Napoleon Bonaparte terhadap Mesir}

Persiapan Ekspedisi. Pasca revolusi 1789, Prancis mulai menjadi negara besar yang mendapat saingan dan tantangan dari Inggris. Sejarah menjelaskan bahwa penyerangan Perancis ke Mesir sesungguhnya memuat misi ekonomi, yakni persaingan wilayah bisnis antara Perancis dan Inggris. Inggris pada waktu sudah menguasai beberapa daerah di Asia antara lain; India, Pakistan, dan sebagainya. Perancis melihat Mesir berada pada jalur perdagangan yang strategis (Philip K. Hitti, 2005 : 924).

Inggris di waktu itu telah mengikatkan kepentingan-kepentingannya di India dan untuk memutuskan komunikasi antara Inggris di Barat dan India di Timur, Napoleon melihat bahwa Mesir perlu diletakkan di bawa kekuasaan Prancis. Di samping itu Prancis membutuhkan pasar baru untuk hasil perindustriannya. Napoleon sendiri kelihatannya mempunyai tujuan sampingan lain. Alexander Macedonia pernah menguasai Eropa dan Asia sampai ke India, dan Napoleon ingin mengikuti jejak Alexander ini (Philip K. Hitti, 2005 : 924). Tempat strategis untuk menguasai kerajaan besar seperti yang dicita-citakannya itu, adalah Kairo dan bukan Roma atau Paris. Inilah beberapa hal yang mendorong Perancis dan Napoleon menduduki Mesir.

Mesir pada waktu itu berada di bawah kekuasaan kaum Mamluk, sungguh pun sejak ditaklukkan oleh Sultan Salim di tahun 1517, daerah ini pada hakikatnya bukan merupakan bagian dari Kerajaan Usmani. Apalagi setelah bertambah lemahnya kekuasaan sultan-sultan di abad ke 17, Mesir mulai melepaskan diri dari kekuasaan Istambul dan akhirnya menjadi daerah otonom. Sultan-sultan Usmani tetap mengirim seorang Pasya Turki ke Kairo untuk bertindak sebagai wakil mereka dalam memerintah daerah ini. Tetapi karena kekuasaan sebenarnya terletak di tangan kaum Mamluk, kedudukannya di Kairo tidak lebih dari kedudukan seorang duta besar. Potret lemahnya pertahanan Kerajaan Usmani dan kaum Mamluk ketika itu, dapat digambarkan dari perjalanan perang di Mesir. Napoleon mendarat di Alexandria pada tanggal 2 Juni 1798 dan kota pelabuhan yang penting ini jatuh sembilan hari kemudian. Rasyid, suatu kota yang terletak di sebelah timur Alexadria, jatuh pula.

Pada tanggal 21 Juli tentara Napoleon sampai di daerah piramid di dekat Kairo. Pertempuran melawan pasukan Prancis terjadi di tempat itu dan kaum Mamluk karena tak sanggup melawan senjata-senjata meriam Napoleon, lari ke Kairo. Tetapi di sini mereka tidak mendapat simpati dan sokongan dari rakyat Mesir. Akhirnya mereka terpaksa lari lagi ke daerah Mesir sebelah selatan. Pada tanggal 22 Juli, tidak sampai tiga minggu setelah mendarat di Alexandaria, Napoleon dapat menguasai Mesir. Pasukan Mamluk menyerah. Sementara bantuan pasukan dari kerajaan Turki Usmani tidak ada.

Usaha Napoleon untuk menguasai daerah-daerah lainnya di Timur Mesir tidak berhasil. Ditambah dinamika politik di Prancis menghendaki kehadirannya di Paris. Pada tanggal 18 Agustus 1799, ia meninggalkan Mesir kembali ke tanah airnya. Ekspedisi yang dibawanya ia serahkan kepada pimpinan Jendral Kleber. Dalam pertempuran yang terjadi di tahun di tahun 1801 dengan armada Inggris, kekuatan Prancis di Mesir mengalami kekalahan. Ekspedisi yang dibawa Napoleon itu akhirnya benar-benar selesai pada tanggal 31 Agustus 1801 (Harun Nasution, 2003: 21-22).

\subsection{Saat Ekspedisi}

Penyerangan Prancis terhadap Mesir terjadi tahun tahun 1798. Tercatat dalam sejarah armada angkatan laut Napoléon berjumlah 40,000 pasukan yang diangkut dengan 13 kapal perang yang besar, 6 kapal perang sedang. Armada ini berangkat dari Toulon, pesisir pantai Mediteranian Prancis pada April 1798. Kapalkapal tersebut melaju melintasi Malta, untuk menghindari pasukan Inggris yang dipimpin oleh Admiral Horatio Nelson, lalu mendarat di dekat pantai Alexandria pada tanggal 1 Juli 1798 (Arthur Goldschmidt, 2008: 63). Pasukan Mamluk, yang sudah berjaga-jaga dengan pedang panjang, lari kocar-kacir tidak mampu menghadang serangan pasukan Perancis. Peralatan perang canggih, seperti meriam-meriam yang bersuara sangat menggelegar tidak mampu dibendung oleh pasukan Mameluk (Afaf Lutfi al-Sayyid Marsot, 2007: 60).

Tantangan pasukan Prancis yang paling berat sesungguhnya bukan tentara Mamluk, melainkan kekuarangan logistik. Ketika melintasi Delta tersebut dan beberapa padang pasir, serta lembah, mereka terserang penyakit diare yang cukup parah. Ditambah kondisi matahari yang sangat panas membuat pasukan-pasukan ini menderita. Dikisahkan pasukan Napoleon lebih banyak mati menderita karena kehausan dan penyakit ketimbang mati tebunuh oleh pasukan Mameluk ketika bertarung di sekitar pyramid (Afaf Lutfi al-Sayyid Marsot, 2007: 66). Setelah berhasil menaklukan pasukan Mameluk di sekitar piramid, pada tanggal 21 Juli 1798 pasukan Prancis memasuki Kairo. Ketika masuk, Napoleon meyakinkan penduduk Mesir dengan pidatonya: "Peoples of Egypt, you will be told that I have come to destroy your religion. This is anobvious lie; do not believe it. Answer back that I have come to restore your rights and to punish the usurpers; that I worship God more than the Mamluks do; and that I respect His prophet Muhammad and the admirable Quran" (Afaf Lutfi al-Sayyid Marsot, 2007: 67).

Mendengar pidato tersebut kebanyakan penduduk muslim Mesir masih tidak yakin dengan ucapan tersebut. Dalam catatan sejarah lainnya menjelaskan untuk menarik simpati masyarakat, Napoleon 
menyebarkan pamphlet di berbagai penjuru kota yang isinya menyatakan bahwa bangsa Mamluk bukanlah Muslim yang baik, tidak seperti Perancis yang datang untuk memulihkan nama baik dan mengembalikan hak-hak mereka. Pamphlet tersebut ditulis dengan bahasa Arab dan diawali dengan basmalah (Siti Maryam, 2003: 353)

\section{Tiga Tahun Menguasai Mesir}

Napoleon tidak lama berkuasa di Mesir. Kurang lebih 3 tahun saja. Setelah diserang oleh pasukan Inggris Prancis akhirnya kembali kandang. Hal menarik dari ekspedisi Napoleon ini adalah pasukannya tidak hanya terdiri dari tentara saja, ia juga membawa 167 artis, sarjana, dan ilmuan (Arthur Goldschmidt, 2008: 174). Dalam catatan lainnya dijelaskan bahwa Napoleon membawa 500 sipil dan 500 kaum wanita. Di antara kaum sipil tersebut 167 adalah ilmuan di berbagai bidang (Siti Maryam, 2003: 354). Ada juga yang memberikan gambaran bahwa jumlah ilmuan yang dibawa jumlahnya 50 orang (Afaf Lutfi al-Sayyid Marsot, 2007: 59). Mereka sengaja dipersiapkan untuk menggali informasi tentang Mesir sedalamdalamnya. Selain itu Napoleon juga membawa dua set alat percetakan dengan huruf latin, Arab, dan Yunani (Afaf Lutfi al-Sayyid Marsot, 2007: 355). Temuan mereka yang berharga diterbitkan dalam 23 Volume dengan Judul Description de l'Égypte, yang isinya menggambarkan ketakjuban orang-orang Eropa terhadap Negeri Fir'aun tersebut.

Selain tujuan penaklukan, para ilmuan dan akademisi yang dibawa Napoleon ditugaskan untuk menerjemahkan hieroglyphics dan mencoba memahami kebudayaan Mesir kuno (Afaf Lutfi al-Sayyid Marsot, 2007: 355). Bagi Napoleon Mesir adalah langkah pertama yang harus ditempuh untuk menciptakan kekuasaan yang besar. Ungkapannya itu dituangkan dalam surat untuk teman perempuanya:

"In Egypt, I found myself freed from the obstacles of an irksome civilization. I was full of dreams... I saw myself founding a religion, marching into Asia, riding an elephant, a turban on my head and in my hand the new Quran that I would have composed to suit my needs" (Afaf Lutfi al-Sayyid Marsot, 2007: $355)$.

Jadi sangat jelas sekali selain penaklukan, misi lain Napoleon juga ilmu pengetahuan. Ia kemudian mendirikan sekolah yang diberi nama Institute d 'Egypte yang terdiri dari empat jurusan: Ilmu pasti, ilmu alam, ekonomi politik, dan sastra-seni. Sekolah ini terbuka untuk umum, bangsa pribumi, dan orang-orang Prancis sendiri. Sekolah ini juga menerbitkan surat kabar yang bernama La Decade Egyptienne. Selain itu, juga ada majalah La Courier d 'Egypte yang diterbitkan oleh Marc Auriel seorang pengusaha yang ikut dalam ekspedisi tersebut (Afaf Lutfi al-Sayyid Marsot, 2007: 355).

Selain mengembangkan ilmu pengetahuan Napoleon juga mengenalkan sistem pemeritahan republik. Napoléon membentuk diwan, semacam pemerintahan sementara yang dibuat oleh French Jenderal penguasa Mesir dan mengangkat beberapa orang ulama dan pengelola tanah. Mereka juga mengurusi masalah perangkat-perangkat desa, seperti memformulasikan hukum perdata dan pidana, mengatur suksesi jabatan pemerintahan, dan merubah undang-undang hak milik dan pajak (Arthur Goldschmidt, 2008: 174).

Apa yang dilakukan Napoleon terhadap bangsa Mesir, sebagaimana tergambar di atas, menjadi bukti bahwa apa yang dilakukannya jauh berbeda dari Mamluk. Napolen memberikan banyak perubahan. Meskipun begitu kelompok Muslim merasa terganggu dengan tabi'at pasukan Prancis yang gemar minumminum di tempat umum, mencuri barang-barang, dan menggoda wanita-wanita lokal.

\section{Pengaruh Ekspedisi Napoleon di Mesir}

Kesadaran atas Keterbelakangan Ilmu Pengetahuan. Kedatangan Napoleon memang untuk melakukan imperialisme (kolonialisme) terhadap Mesir. Namun, agenda peradaban yang dibawa Napoleon memberikan dianggap positif bagi bangsa Mesir. Kedatangan Napoleon tidak dapat dibantah dapat membuka mata bangsa Mesir terhadap pengetahuan tentang dan ketinggian peradaban Perancis. Hal ini membersitkan isyarat bahwa Mesir dan Dunia Arab umumnya saat itu berada di alam kegelapan dan keterbelakangan.

Ekspedisi Napoleon memang berorientasi militer, tetapi juga mengandung nilai ilmiah. Semangat dan keperluan ilmiah Napoleon terlihat dari dibentuknya lembaga ilmiah bernama Institut d'Egypte yang mempunyai empat bidang bahasan; Bagian Ilmu Pasti, bagian Ilmu Alam, Bagian Ekonomi-Politik dan Bagian Sastra-Seni. Untuk mendukung program tersebut, Napoleon beserta rombongannya membawa peralatan yang terbilang canggih pada waktu itu, yaitu dua set percetakan huruf Latin Arab, dan Yunani. Selain itu juga alat-alat perlengkapan Ilmu Alam seperti teleskop, mikroskop, dan percobaan-percobaan kimiawi dan sebagainya. Ditambah dengan sarana bantu berupa perpustakaan besar yang menghimpun buku-buku dalam berbagai bahasa Eropa dan buku-buku agama dalam bahasa Arab, Persia, dan Turki, yang terbilang lengkap.

Institut d'Egypte boleh dikunjungi orang Mesir, terutama para ulamanya. Harapannya dengan kehadiran para ulama-ulama tersebut, dapat diajak bekerjasama dan membatu lembaga itu, untuk 
menambah pengetahuan mereka tentang Mesir, seperti adat istiadat, bahasa, dan agamanya. Di sinilah orang-orang Mesir pertama kali mempunyai kontak langsung dengan peradaban Eropa yang baru dan asing bagi mereka.

Abd al-Rahman al-Jabarti, seorang ulama dari al-Azhar dan penulis sejarah, pernah mengunjungi lembaga itu di tahun 1799. Hal yang menarik perhatiannya adalah perpustakaan besar yang mengandung buku-buku, bukan hanya dalam bahasa-bahasa Eropa, tetapi juga buku-buku agama dalam bahasa Arab, Persia, dan Turki. Di antara ahli-ahli yang dibawa Napoleon memang terdapat kaum orientalis yang pandai dan mahir berbahasa Arab. Merekalah yang menerjemahkan perintah dan maklumat-maklumat Napoleon ke dalam bahasa Arab.

Alat-alat kimia seperti teleskop, mikroskop, alat-alat untuk percobaan kimiawi, dan sebagainya lengkap berada di institut tersebut. Eksperimen-eksperimen yang dilakukan di lembaga itu, kesungguhan orang Perancis bekerja dan kegemaran mereka pada ilmu-ilmu pengetahuan, semua itu menakjubkan bagi alJabarti. Kesimpulan tentang kunjungan itu ia tulis dengan kata-kata berikut:

"Saya lihat di sana benda-benda dan percobaan-percobaan ganjil dan asing yang menghasilkan hal-hal yang besar untuk dapat ditangkap oleh akal seperti yang ada pada diri kita" (Harun Nasution, 2003: 29).

Demikianlah kesan seorang cendekiawan Islam waktu itu terhadap Barat, khususnya Prancis. Pernyataan tersebut menggambarkan betapa mundurnya umat Islam saat itu. Keadaan menjadi berbalik 180 derajat. Dahulu di periode klasik (1250-1800) (Wahyudin Darmalaksana, 2009: 122) sejarah Islam, orang Barat yang kagum melihat kebudayaan dan peradaban Islam. Di periode Modern kaum Muslim yang heran melihat kebudayaan dan kemajuan barat.

Keuntungan positif inilah yang nantinya menghidupkan gairah intelektual bangsa Mesir. Setelah peristiwa itu bangsa Mesir mulai terbuka dan kemudian gencar mengambil —mengadopsi dan mengadaptasi-peradaban Barat dalam berbagai hal. Terkait dengan cara beragama, peristiwa tersebut memantik bangkitnya kesadaran bahwa selama ini umat telah salah kaprah dalam memahami ruh perubahan yang terdapat dalam al-Qur'an. Meraka akhirnya mengakui, bahwa Barat yang tidak secara langsung diilhami oleh spirit al-Qur'an pun dapat maju dan jaya karena pola hidup dan orientasi akal yang benar. Padahal yang dilakukan Barat barulah hal kecil dari isi kandungan al-Qur'an.

Setelah persentuhan itulah, umat Islam di Mesir mulai menata diri dan merumuskan semacam ideologi pembaruan secara rasional. Menata kembali model pendidikan yang menghargai akal. Menggairahkan kehidupan ilmu pengetahuan. Merumuskan perekonomian, membangun budaya maju, dan berbagai hal lainnya dengan cermin Barat.

\subsection{Kebebasan dan Kemerdekaan}

Dampak dari ekspedisi Napoleon dirasakan tidak seketika. Setelah Pasukan Napoleon berhasil dipukul Inggris dan kembali ke Prancis, Mesir jatuh kembali pada kekuasaan Inggris. Namun setidaknya pengalaman bersama perancis sangat membekas dan memberikan pelajaran penting untuk melawan Inggris. Barulah setelah Muhammad Ali (Bahasa Mesir: Mehmet Ali) (1769-1849) berkuasa, salah seorang reformer Mesir berkebangsaan Albania, ide-ide Napoleon banyak digunakan (Wahyudin Darmalaksana, 2009: 66). Sebagai misal ide tentang kebebasan dan kemerdekaan. Kedatangan Napoleon dengan propaganda yang halusinatif tersebut rupanya mendorong perubahan di berbagai lini kehidupan masyarakat Mesir. Masyarakat melihat bahwa kebebasan itu merupakan hal mutlak yang harus diperjuangkan.

Mehmet Ali berhasil meraih simpatik masyarakat dan menggeser dominasi Mamluk. Faksi Mamlukpun akhirnya juga ikut mendorong Mehmet Ali untuk meneruskan ide-ide reformasi tersebut. Kesultanan akhirnya juga dihilangkan. Pada saat itulah babak baru Mesir modern bermulai (Wahyudin Darmalaksana, 2009: 66).

\subsection{Reformasi Agraria}

Mehemet Ali juga meneruskan gagasan Napoleon yang membuat saluran air di lembah Sungai Nil, sehingga hasil pertaniannya berlibat ganda. Ia mengerahkan tentara untuk mengembangkan saluran irigasi. Ia juga memberikan pajak yang besar terhadap hasil panen sebagaimana kekuasaan Mamluk, namun itu dilakukan untuk membayar pasukan lebih besar. Sesekali campur tangan pemerintah cukup kuat, bahkan bisa dikatakan sering memonopoli kondisi perdagangan. Namun itu dilakukan untuk mempercepat laju ekonomi, dan akhirnya pada saat itu Mesir sudah dapat menghasilkan berbagai bahan untuk dijual di pasar internasional seperti: kapas, cengkeh, tembakau, gandum dan sebagainya (Wahyudin Darmalaksana, 2009: 67).

Pertumbuhan penduduk pun akhirnya meningkat. Di awal abad 18 jumlah penduduk berkisar 3.8 juta jiwa, dan di tahun 1880 meningkat menjadi 7.5 juta jiwa. Artinya kondisi Mesir mulai membaik, kesejahteraan mulai terbangun. 


\subsection{Peningkatan Industrialisasi}

Pada kepemimpinan Mehmet Ali, industrialisasi mulai ditingkatkan. Setelah berhasil menekan laju pertanian, kemudian industrialisasi ditingkatkan. Pabrik-pabrik dibangun. Mendatangkan mesin-mesin dari luar negeri dan insinyur dan manajer dari luar negeri. Semangat ini juga membuat pekerja dalam negeri kepayahan. Karena mereka dipaksa kerja lebih keras dengan waktu yang lebih lama. Beberapa produk industri yang dihasilkan adalah sabun, kertas, pakaian (konvenksi), kapal perang, perlengkapan perang. Kerja keras ini akhirnya menjadikan Mesir sebagai negara Arab pertama yang ikut dalam percaturan industri dunia (Wahyudin Darmalaksana, 2009: 68).

Untuk menopang itu semua, sekolah-sekolah model Napoleon juga dikembangkan. Dibuka fakultasfakultas kedokteran, administrasi, bahasa, dan kerajinan untuk menopang semangat industri tersebut (Wahyudin Darmalaksana, 2009: 68).

\subsection{Peningkatan Kekuatan Militer}

Kekalahan perang melawan Prancis akhirnya mendorang pemeritah untuk belajar militer. Pada tahun 1821 banyak dari para budak diangkat menjadi tentara (Wahyudin Darmalaksana, 2009: 68). Para budak pun menjadi senang karena statusnya berubah. Pasukan Janisari yang terkenal loyal dengan kerajaan Turki Usmani dibubarkan. Karena dianggap membahayakan dan berpotensi melakukan pemberonrakan (Siti Maryam, 2003: 358). Kemudian mereka dilatih oleh Kolonel Stive, berkebangsaan Perancis, dan setelah masuk Islam ia berubah nama menjadi Sulaiman Pasya.

\subsection{Demokrasi dan Sistem Pemerintahan Republik}

Di Mesir sepanjang sejarah sistem pemerintahan bersifat absolut dan monarki. Seorang kepala negara dipilih oleh parlemen yang berkuasa dalam masa tertentu dan harus tunduk kepada undang-undang dasar merupakan hal baru yang diperlihatkan Napoleon. Apalagi UUD itu sendiri dibuat bukan oleh kepala negara atau raja melainkan oleh parlemen. Parlemenlah yang menentukan kredibiltas seorang kepala negara, yang kalau menyimpang dari kedudukannya.

\subsection{Ide Persamaan (egalite)}

Ide persamaan atau egalite, yaitu adanya persamaan kedudukan antara penguasa dengan rakyat yang diperintah, serta turut berperan aktifnya rakyat dalam pemerintahan. Sebelumnya rakyat Mesir tidak tahu menahu dalam soal pemerintahan, maka ketika Napoleon mendirikan suatu badan kenegaraan yang terdiri dari ulama-ulama Al-Azhar dan pemuka-pemuka dalam dunia bisnis dari Kairo dan daerah-daerah. Tugas badan ini membuat UU, memelihara ketertiban umum dan menjadikan perantara penguasa-penguasa Perancis dengan rakyat Mesir. Di samping itu dibentuk pula suatu badan yang bernama Diwan Al-Ummah yang pada waktu tertentu mengadakan sidang untuk membicarakan hal-hal yang bersangkutan dengan kepentingan nasional (Siti Maryam, 2003: 355).

\subsection{Model Keberagamaan yang Rasional}

Berkembanya industrialisasi mau tidak mau juga merubah cara beragama orang-orang Mesir. Semula yang dominan adalah paham fatalisme dan tasawuf, di era industrialisasi yang menghendaki rasionalitas, muncul paham keberagmaan yang progresif.

Dalam hal ini Ibrahim Abu Rabi membagi paradigma beragama di Mesir menjadi tiga model; Pertama, tradisionil, artinya kelompok masyarakat yang cara beragamanya masih kolot, menolak perubahan dan modernisasi. Meniru barat adalah awal kehancuran. Kedua, adalah kelompok scientific trend. Kelompok ini mengandalkan rasionalitas murni dan perkembangan ilmiah zaman. Kelompok ini benar-benar takjub terhadap barat, karena barat sudah membuka mata mereka terhadap zaman. Ketiga, kelompok sintetik. Kelompok ini adalah kelompok moderat yang rasional (Siti Musdah Mulia, 2001: 30) Ia melihat barat di satu sisi harus ditiru, namun disisi yang lain tetap kritis, khususnya terhadap masalah prilaku yang terkadang tidak sesuai dengan perintah agama. Dari kelompok inilah lahir banyak tokoh dunia, diantaranya, Muhammad Abduh, Thahtowi, Rasyid Ridha, Muhammad Husain Haekal, dan sebagainya.

Paradigma inipula yang menginisiasi semangat reformasi pendidikan dalam Islam. Bahwa harus ada perubahan cara beragama dan belajar agama. Agama tidak menjadi doktrin dan harus solutif terhadap zaman.

\section{KESIMPULAN}

Setelah mengkaji panjang lebar, didapatlah kesimpulan sebagai berikut: Kondisi Mesir sebelum terjadinya ekspedisi Napoleon sangat mundur di segala bidang, baik pendidikan, agama, sosial, ekonomi, dan politik. Adapun perubahan yang terjadi di Mesir pasca Napoleon antara lain; (1) dalam bidang pendidikan munculkan kesadaran akan keterbelakangan ilmu pengetahuan, dibangunya berbagai 
infrastruktur pendidikan, mengakui pentingnya kebebasan dan kemerdekaan dalam perkembangan ilmu pengetahuan; (2) Mendorong perubahan cara pandang dan model beragama ke arah yang lebih rasional dan solutif terhadap perubahan zaman, fanatisme terhadap satu madzhab mulai ditinggalkan, pemahaman jabariyah mulai bergeser ke arah ikhtiyar; (3) dalam bidang sosial dan budaya lahirlah gagasan persamaan (legalite) dan kesetaraan antara penguasa dan rakyat serta berkembangnya tekhnologi peperangan, persenjataan, dan latihan militer yang diadopsi dari Perancis; (4) dalam bidang politik memunculkan ide kebangsaan (nasionalisme) dan pemerintahan republik; dan (5) dalam bidang ekonomi mendorong perkembangan industrialisasi dan reformasi agraria.

\section{REFERENSI}

Afaf Lutfi al-Sayyid Marsot, 2007. A History of Egypt: From the Arab Conquest to the Present, New York: Cambridge University Press.

Anhar Anshari, 2019, Kuliah Kemuhammadiyahan Gerakan Pembaruan, Yogyakarta: UAD Press.

Arthur Goldschmidt Jr., 2008. A Brief History of Egypt, New York: Pennsylvania State University,

Arnold Toynbee, tt, Sejarah Umat Manusia: Uraian Analitis, Kronologis, Naratif, dan Komparatif, Yogyakarta: Pustaka Pelajar.

Badri Yatim, 2000, Sejarah Peradaban Islam, Jakarta: Rajawali Press.

Hamka, 1975, Sejarah Ummat Islam Jilid II, Jakarta: Bulan Bintang.

Harun Nasution, 2003. Pembaharuan Dalam Islam Sejarah Pemikiran dan Gerakan, Cet. XIV, PT. Jakarta: Bulan Bintang. 1986, Pembaharuan dalam Islam, Jakarta: Bulan Bintang.

Ibrahim Abu Rabi, 2004, Contemporary Arab Thought: Studies In Post-1967 Arab Intellectual History, London: Pluto Press.

Kaelan, 2010, Metode Penelitian Agama dan Filsafat, Yogyakarta: Pustaka Pelajar.

Muhammad Al-Bahy, 1986, Pemikiran Islam Modern, Pustaka, Panjimas, Jakarta.

Mukti Ali, 2000, Ijtihad dalam Pandangan Muhammad Abduh, Akhmad Dahlan, dan Muhammad Iqbal, Jakarta: Bulan Bintang.

Nourouzaman As-Sidiqi, 1989, Pengantar Sejarah Muslim, Yogyakarta: Mentari Masa.

Philip K. Hitti, 2005, History of Arabs, Jakarta: Serambi.

Siti Maryam, dkk., 2003, Serjarah Peradaban Islam, Yogyakarta: Jurusan SPI Fakultas Adab dan LESFI.

Siti Musdah Mulia, 2001, Negara Islam: Pemikiran Politik Husain Haekal, Jakarta: Paramadina.

Stvelana Kirillina, "Cultural and Intellectual Exchange between the Ottoman Egypt and the Rest of the Arab Muslim Wodd in the Eighteenth - Early Nineteenth Century" dalam Al-Jami'ah, vol. 42, No.1, 2004/1425 $\mathrm{H}$

T. Al-Tanawi, tt, Muzzakir Al-Imam Muhammad Abduh, Qahirah: Darul Hilal.

Wahyudin Darmalaksana, “Dinasti Mamalik di Mesir”, dalam el-Harakah Vol.11, No.2, Tahun 2009. 